University of Nebraska - Lincoln

DigitalCommons@University of Nebraska - Lincoln

2003

\title{
Effect of Feeding Glyphosate-Tolerant (Roundup-Ready Events GA21 or nk603) Corn Compared with Reference Hybrids on Feedlot Steer Performance and Carcass Characteristics
}

\author{
Galen Erickson \\ University of Nebraska-Lincoln, gerickson4@unl.edu
}

N. D. Robbins

University of Illinois, Urbana, IL

\section{J. J. Simon}

University of Nebraska-Lincoln

L. L. Berger

University of Illinois, Urbana, IL, Iberger2@unl.edu

Terry Klopfenstein

University of Nebraska-Lincoln, tklopfenstein1@unl.edu

See next page for additional authors

Follow this and additional works at: https://digitalcommons.unl.edu/animalscifacpub

Part of the Animal Sciences Commons

Erickson, Galen; Robbins, N. D.; Simon, J. J.; Berger, L. L.; Klopfenstein, Terry; Stanisiewski, E. P.; and Hartnell, G. F., "Effect of Feeding Glyphosate-Tolerant (Roundup-Ready Events GA21 or nk603) Corn Compared with Reference Hybrids on Feedlot Steer Performance and Carcass Characteristics" (2003). Faculty Papers and Publications in Animal Science. 457.

https://digitalcommons.unl.edu/animalscifacpub/457

This Article is brought to you for free and open access by the Animal Science Department at DigitalCommons@University of Nebraska - Lincoln. It has been accepted for inclusion in Faculty Papers and Publications in Animal Science by an authorized administrator of DigitalCommons@University of Nebraska - Lincoln. 


\section{Authors}

Galen Erickson, N. D. Robbins, J. J. Simon, L. L. Berger, Terry Klopfenstein, E. P. Stanisiewski, and G. F. Hartnell 


\title{
Effect of feeding glyphosate-tolerant (Roundup-Ready events GA21 or nk603) corn compared with reference hybrids on feedlot steer performance and carcass characteristics ${ }^{1}$
}

\author{
G. E. Erickson*2, N. D. Robbins $\dagger$, J. J. Simon*, L. L. Berger $\dagger^{3}$ T. J. Klopfenstein*, \\ E. P. Stanisiewski \\ *Department of Animal Science, University of Nebraska, Lincoln 68583-0908; \\ $\dagger$ Department of Animal Science, University of Illinois, Urbana, IL 61801; and \\ $\ddagger$ Monsanto Company, St. Louis, MO 63167
}

\begin{abstract}
Three experiments were conducted to compare the feeding value of genetically enhanced corn (Roundup Ready corn events GA21 and nk603) with nontransgenic hybrids. The four treatments included two separate reference hybrids (REF), the near-isogenic control hybrid (CON), and the genetically enhanced corn (RR), resulting in two preplanned comparisons of CON vs. RR and RR vs. the average of REF. In Exp. 1 $(\mathrm{RR}$ event GA21), 175 steers $(\mathrm{BW}=427 \mathrm{~kg})$ were fed in 25 pens with seven pens per corn hybrid, except CON, which contained four pens due to limited quantities of that hybrid. In Exp. 2 (RR event nk603), 196 steers $(\mathrm{BW}=420 \mathrm{~kg})$ were fed in 28 pens with seven pens per corn. In Exp. 3 (RR event nk603), 200 steers were fed in 20 pens, with a similar treatment design to Exp. 2 and five pens per corn. All experiments were conducted as completely randomized designs and utilized corn produced at University of Illinois (Exp. 1 and 2) and University of Nebraska (Exp. 3) research farms under iden-
\end{abstract}

tity-preserved protocols. In all experiments, DMI, ADG, and feed efficiency were similar $(P>0.30)$ between RR and REF. In Exp. 1 and Exp. 2, RR was not different $(P>0.25)$ than $\mathrm{CON}$ for growth performance. In Exp. 3 , RR was not different from CON for ADG and DMI $(P>0.15)$ or for feed efficiency $(P=0.08)$. No differences were observed between RR and CON or RR and REF for carcass weight, longissimus dorsi area, and marbling scores in any of the experiments. Subtle differences were observed between $\mathrm{RR}$ and either $\mathrm{CON}$ or REF for fat depth in each experiment; however, cattle fed RR were not consistently greater and varied from either the CON or the REF (but not both contrasts) within an experiment. Based on these results, insertion of glyphosate-tolerant genes had no significant effect on nutritive quality of corn. Performance and carcass characteristics were not influenced, which suggests that Roundup Ready corn is similar to conventional, nontransgenic corn when fed to finishing feedlot cattle.

Key Words: Animal Nutrition, Cattle, Finishing, Maize, Transgenic Plants

(c)2003 American Society of Animal Science. All rights reserved.

J. Anim. Sci. 2003. 81:2600-2608

\section{Introduction}

Biotechnology has been adopted throughout many facets of modern production agriculture. These innovations resulted in corn designed to be tolerant to glyphosate herbicides that have minimal soil leaching and low toxicity to mammals, birds, and fish (Sidhu et al., 2000).

\footnotetext{
${ }^{1}$ Published with the approval of the director as paper no. 13704, journal ser., Nebraska Agric. Res. Div.

${ }^{2}$ Correspondence: C220 Animal Science (phone: 402-472-6402; fax: 402-472-6362; E-mail: geericks@unlnotes.unl.edu).

${ }^{3}$ Current address: 1207 W. Gregory Dr. (phone: 217-333-2006; fax: 217-244-3169; E-mail: 1-berger@uiuc.edu).

Received June 20, 2002.

Accepted May 16, 2003.
}

Genetic engineering is one form of biotechnology that is used to enhance the agronomic characteristics of plants by inserting a gene or sequence of genes that express desirable traits. Modern use of genetically engineered crops has increased substantially. Between 1998 and 1999, the usage of genetically enhanced crops increased $44 \%$ globally (27.8 vs. 39.9 million ha; Clark and Ipharraguerre, 2001). Soybean acres planted that were genetically enhanced were $68 \%$ and $75 \%$ in 2001 and 2002 , respectively, while corn acres planted as genetically enhanced crops increased from $26 \%$ to $34 \%$ for those years in the United States (USDA, 2002).

Glyphosate is a commercial herbicide that inhibits the enzyme 5-enolpyruvylshikimate-3-phosphate synthase, which plays an important role in the shikimate acid pathway that synthesizes essential aromatic amino acids required for plant growth (Steinrücken and 
Amrhein, 1980). Few data exist on the effect of feeding Roundup Ready corn to livestock. Because the majority of transgenic corn is fed to livestock, the nutritional quality along with agronomic value must be assessed.

The hypothesis was that feedlot cattle fed Roundup Ready corn will perform similar to cattle fed nontransgenic corn (i.e., the nutritional quality of corn is not changed as a result of Roundup Ready technology). The objective of this research was to compare growth performance and carcass characteristics of finishing steers fed Roundup Ready corn (event GA21 and nk603) to their near-isogenic control hybrid and two reference (nontransgenic) hybrids.

\section{Materials and Methods}

Steers used in these experiments were managed according to the guidelines recommended in the Guide for the Care and Use of Agricultural Animals in Agriculture Research and Teaching (Consortium, 1988). Procedures and animal care were approved by the University of Illinois Lab Animal Care Committee (Exp. 1 and Exp. 2 ) and the University of Nebraska Institute for Animal Care and Use Committee (Exp. 3).

\section{Experiment 1}

Animals. This experiment was conducted at the University of Illinois Beef Research Unit in Urbana. The experiment lasted from January 5 through April 6, 2000 (92 d). One hundred seventy-five Angus-continental cross steers were assigned randomly to 25 pens on December 13, 1999, for a 20-d diet adjustment period, during which steers were adapted to final finishing diets by decreasing corn silage (nontransgenic) concentration from 35, to 25, to $15 \%$ (DM basis) and increasing corn at intervals of 6,7 , and $7 \mathrm{~d}$, respectively. Steers were vaccinated upon arrival at the feedlot against Clostridium and Haemophlis somnus (Ultrabac 7/Somubac, Pfizer, Exton, PA), infectious bovine rhinotracheitis, bovine viral diarrhea, parainfluenza-3, bovine synctical respiratory virus (ViraShield 5, Grand Laboratories, Freeman, SD), and Pasturella haemolytica (One Shot, Pfizer, Exton, PA). Steers were implanted with Component TE-S with Tylan (TE-S, VetLife-Ivy Laboratories, Overland Park, KS) prior to the adaptation period. Steers were weighed individually on two consecutive days at the start and end of the experiment in the morning prior to feeding, and individual interim weights were taken at 28-d intervals. Final live weight was calculated by dividing hot carcass weight by the average dressing percentage, $61.90 \%$. Steers were housed in pens with solid concrete floors (dimensions $4.3 \mathrm{~m} \times 12.2 \mathrm{~m}$ ) under an open front building facing south. All steers were placed in clean pens with 5 to 8 $\mathrm{cm}$ of wood shavings for bedding. Environmental conditions for the animals were consistent between treatments (i.e., floor space, temperature, lighting, animal density, feeder and water space). Animals were offered feed and water for ad libitum consumption. Feed was delivered once daily in the morning via a Data Ranger mixer (Model B113C; American Calan, Northwood, NH) with an onboard scale to deliver total mixed diets to individual pens. Scales were calibrated prior to initiation of the experiment.

Treatments. Pens were assigned randomly to treatment with seven pens each being fed either the reference hybrids or the Roundup Ready corn. Due to limited quantities, only four pens were fed the near-isogenic control line. Four diets were formulated with different corn hybrids (Table 1). The four treatment diets consisted of 75\% corn from one of either reference hybrid RX826 (REF1; Asgrow, Des Moines, IA), reference hybrid RX730 (REF2), near-isogenic control hybrid DK626 (CON; DEKALB Seeds, Dekalb, IA), or the test hybrid containing genetic modification for glyphosate tolerance (RR) event GA21 in hybrid line DK626. All corn hybrids were grown in Illinois, ground through a tub grinder (AGCO Farmhand, Duluth, GA; 1.9-cm screen), and stored in bottom unloading Harvestore silos as dry corn $(<15 \%$ moisture). Particle-size analysis was conducted by the dry-sieving method, and no differences existed between corn hybrids following processing. Feed mixing equipment (Data Ranger; American Calan Inc., Northwood, NH) was flushed with corn silage between each batch to avoid cross-contamination. All diets were formulated to meet or exceed the NRC (1996) recommendations for finishing steers. Samples of totally mixed diets were sampled weekly and saved for nutrient analysis. The four corns were analyzed for $\mathrm{CP}$, ash, ether extract (AOAC, 1999), and $\mathrm{Ca}, \mathrm{P}, \mathrm{Mg}$, and $\mathrm{K}$ by inductively coupled plasma spectrometry to determine the nutrient profile of each hybrid (Dairy One, DHI Forage Analysis Laboratory, Ithaca, NY). The lowest nutrient concentrations of the four corns were used in formulating the supplement to meet dietary requirements. All diets contained monensin $(29.8 \mathrm{mg} /$ kg DM: Elanco Animal Health, Indianapolis, IN) and tylosin (11.1 mg/kg DM; Elanco Animal Health, Indianapolis, IN).

Carcasses. One hundred sixty steers were marketed at a commercial abattoir (IBP, Joslin, IL) when visually appraised to have $1.0 \mathrm{~cm}$ of subcutaneous fat. Individual carcass measurements were taken for carcass weight, incidence of liver abscesses, 12th-rib fat, kidney, pelvic, and heart (KPH) fat, USDA-called marbling score, and longissimus dorsi area (REA). Dressing percentage and yield grade were calculated using these data. Fourteen steers (one pen from RR, and one CON) were slaughtered separately at the University of Illinois Meats abattoir to conduct more complete sampling of the carcass for gene testing (data not shown). Similar carcass measurements were collected on those steers and included in the analysis. A trained University of Illinois employee assigned marbling scores to all carcasses. Marbling scores for both groups were assigned as follows: $400=$ slight, $500=$ small, $600=$ modest, 700 $=$ moderate, $800=$ slightly abundant, $900=$ moderately 
Table 1. Finishing diet composition fed to finishing steers in Exp. 1, Exp. 2, and Exp. 3. Corn grain was the variable changed in each treatment diet $^{a}$

\begin{tabular}{|c|c|c|c|}
\hline Ingredient & Exp. $1^{b}$ & Exp. $2^{\mathrm{c}}$ & Exp. $3^{c}$ \\
\hline Reference 1 (REF1) & 75 & 73 & 79.5 \\
\hline Reference 2 (REF2) & 75 & 73 & 79.5 \\
\hline Near isogenic control (CON) & 75 & 73 & 79.5 \\
\hline Roundup Ready (RR) & 75 & 73 & 79.5 \\
\hline Corn silage & 10 & 12 & - \\
\hline Steep liquor & 5 & 5 & 10 \\
\hline Alfalfa hay & - & - & 7.5 \\
\hline \multicolumn{4}{|l|}{ Dry supplement ${ }^{\mathrm{d}}$} \\
\hline Soybean meal $(48 \% \mathrm{CP})$ & 7.23 & 5.04 & - \\
\hline Limestone & 1.55 & 1.39 & 1.39 \\
\hline Urea & 0.50 & 0.46 & 0.29 \\
\hline Salt ${ }^{\mathrm{e}}$ & 0.30 & 0.28 & 0.30 \\
\hline Potassium chloride & 0.20 & 0.10 & - \\
\hline Tallow & 0.20 & 0.28 & 0.10 \\
\hline Trace mineral $^{\mathrm{f}}$ & - & - & 0.03 \\
\hline Rumensin premix ${ }^{g}$ & 0.016 & 0.016 & 0.017 \\
\hline Tylan premix ${ }^{\mathrm{h}}$ & 0.013 & 0.013 & 0.011 \\
\hline Vitamins $A, D, E^{\mathrm{i}}$ & 0.010 & 0.010 & 0.010 \\
\hline Copper sulfate & - & 0.005 & - \\
\hline \multicolumn{4}{|l|}{ Composition $^{\mathrm{j}}$} \\
\hline $\mathrm{CP}$ & 13.5 to 16.3 & 12.5 to 13.4 & 12.1 to 13.1 \\
\hline Calcium & 0.61 to 0.91 & 0.52 to 0.65 & 0.65 to 0.66 \\
\hline Phosphorus & 0.34 to 0.40 & 0.33 to 0.38 & 0.54 to 0.58 \\
\hline Potassium & 0.73 to 0.93 & 0.75 to 0.87 & 0.79 to 0.84 \\
\hline
\end{tabular}

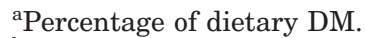

${ }^{\mathrm{b}} \mathrm{REF} 1$ = Reference (Asgrow RX826), REF2 = Reference (Asgrow 730), CON = Near isogenic control (DK626), $\mathrm{RR}=$ Roundup Ready (DK626RR; event GA21) corn.

${ }^{c}$ REF1 = Reference DEKALB hybrid DK647, REF2 = Reference Asgrow hybrid RX740, CON = Near isogenic control hybrid RX670, and RR = Roundup Ready hybrid (event nk603).

${ }^{\mathrm{d} S u p p l e m e n t ~ f e d ~ i n ~ m e a l ~ f o r m ~ a n d ~ f o r m u l a t e d ~ t o ~ b e ~ f e d ~ a t ~ 10 \% ~(E x p . ~} 1$ and Exp. 2) or 3\% of diet DM (Exp. 3) and were identical across treatments within each experiment.

eTrace mineral salt with Se, composition is salt: 81 to $86 \%$, Fe: $2.57 \%, \mathrm{Zn}: 2.86 \%, \mathrm{Mn}: 5,710 \mathrm{mg} / \mathrm{kg}, \mathrm{Cu}$ : $2,290 \mathrm{mg} / \mathrm{kg}$, I: $100 \mathrm{mg} / \mathrm{kg}$, Se: $85.7 \mathrm{mg} / \mathrm{kg}$.

${ }^{f}$ Premix contained $12 \% \mathrm{Zn}, 10 \% \mathrm{Fe}, 8 \% \mathrm{Mn}, 1.5 \% \mathrm{Cu}, 0.2 \% \mathrm{I}, 0.10 \% \mathrm{Co}$.

gPremix contained $176 \mathrm{~g} / \mathrm{kg}$ Monensin.

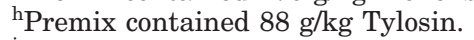

${ }^{i}$ Premix contained 3,300 IU vitamin A, 330 IU vitamin D, 44 IU vitamin E per gram (Exp. 1 and Exp. 2) and 1,500 IU vitamin A, 3,000 IU vitamin D, 3.7 IU vitamin E per gram (Exp. 3).

${ }^{j}$ Based on composited ingredient samples (Analysis by Dairy One, Ithaca, NY).

abundant, $1,000=$ abundant. A cross section $(0.8-\mathrm{cm}$ thick) of longissimus thoracis muscle was collected from each carcass and analyzed for fat by acid hydrolysis, protein by Kjeldahl N, and water content (AOAC, 1999). Longissimus muscle area was determined by use of images transposed onto chromatography paper and then traced and counted on a grid. Yield grade was calculated using fat depth, longissimus area, carcass weight, and KPH fat (Meat Evaluation Handbook, 2001).

One steer was removed from the study due to a broken leg suffered during weighing. It was assumed that the steer consumed the same amount as the pen up to its removal on $\mathrm{d} 28$.

\section{Experiment 2}

Animals. One hundred ninety-six Angus-continental cross steers were allotted on December 13, 2000, for a diet adjustment period at the University of Illinois Beef Research Unit in Urbana. Steers were all implanted with Component TE-S (TE-S, Vetlife-Ivy Laboratories, Overland Park, KS) prior to the adjustment period. Steer allotment facilities, vaccinations, diet formulation, and management were the same as Exp. 1, with the exception that 28 pens of steers were allotted to the four corn treatments (seven pens/corn). No steers were removed prior to study completion.

Treatments. Treatments were assigned randomly to each pen so that each treatment was represented once within a grouping of four pens to minimize potential variation due to pen location. All corn hybrids used for this experiment were grown on the University of Illinois farm. The treatments consisted of using either a Roundup Ready hybrid with event nk603 (RR), the near isogenic control hybrid RX670 (CON), reference hybrid DK647 (REF1; DEKALB Seeds, Dekalb, IA), or reference hybrid RX740 (REF2; Asgrow, Des Moines, IA) fed at $73 \%$ of diet DM (Table 1). The four hybrids were analyzed at a commercial laboratory (Dairy One, DHI Forage Analysis Laboratory, Ithaca, NY), and supple- 
ments formulated as in Exp. 1. The experiment lasted from January 3 through April 7, 2001 (94 d).

Initial and final BW were based on the average of two weights taken on consecutive days. Similar to Exp. $1, \mathrm{ADG}$ and feed efficiency (ADG/DMI) were calculated based on carcass adjusted final weights.

Carcasses. Steers were marketed at a commercial abattoir (IBP, Joslin, IL). Hot carcass weights and the incidence of liver abscesses were collected following slaughter. Hot carcass weights were used to calculate final BW for each steer by dividing hot carcass weight by the average dressing percentage (61.1\%). Average dressing percentages were calculated as carcass weight divided by final live weights collected on two consecutive days before slaughter. Remaining carcass measurements included 12th-rib fat thickness, KPH, and USDA-called marbling scores at the 12th rib, which were measured $24 \mathrm{~h}$ after harvest. Samples of longissimus muscle were collected approximately $24 \mathrm{~h}$ postharvest and analyzed similar to Exp. 1.

\section{Experiment 3}

Animals. Two hundred crossbred steers were used in a completely randomized design to evaluate the effects of Roundup Ready (event nk603) corn on finishing performance and carcass composition. The steers were received at the University of Nebraska Agricultural Research and Development Center, Ithaca, NE, in the Fall of 2000 and grazed on corn residues while being supplemented with wet corn gluten feed until January 2001. After $5 \mathrm{~d}$ of limit feeding 50\% alfalfa:50\% wet corn gluten feed (DM basis) at $2 \%$ of BW, BW were recorded individually on two consecutive days in the morning prior to feeding for determination of initial BW $(321 \pm 13 \mathrm{~kg})$. Individual weights were recorded every $28 \mathrm{~d}$ until market (144 d). Steers were implanted with Ralgro (Schering-Plough Animal Health, Union, $\mathrm{NJ}$ ) at the beginning of the experiment and reimplanted on d 56 with Revalor-S (Intervet Inc., Somerville, NJ).

Treatments. Steers were assigned to treatment by stratified weight recorded on $\mathrm{d} 0$ and allocated to one of 20 pens ( 10 steers/pen) by random number. Pens were assigned randomly to one of four treatments. The treatment design was similar to Exp. 2, and the same four treatments were used. Five pens (replications) with 10 steers/pen were used for each treatment. All diets were formulated to meet or exceed NRC (1996) recommendations for digestible intake protein, undigestible intake protein, $\mathrm{Ca}, \mathrm{P}$, and $\mathrm{K}$. Due to slight differences in nutrient analysis, the corn with the lowest content of $\mathrm{CP}$ ( RR corn, 8.5\% $\mathrm{CP}$ ) was used as the input in the formulation model, so that any differences in performance would not be related to protein differences among treatments. Steers were adapted to final diets by replacing alfalfa hay with the treatment corn. Adaptation diets contained $45,35,25$, and $15 \%$ roughage fed for $7 \mathrm{~d}$ each. The final diet after $28 \mathrm{~d}$ consisted of $79.5 \%$ dry-rolled corn and $7.5 \%$ ground alfalfa hay
(DM basis; Table 1). All diets contained monensin (29.7 $\mathrm{mg} / \mathrm{kg}$ DM; Elanco Animal Health, Indianapolis, IN) and tylosin $(9.9 \mathrm{mg} / \mathrm{kg}$ DM; Elanco Animal Health, Indianapolis, IN) similar to current industry standards. The low moisture content of each of the corn hybrids (10.2 $\pm 1.0 \%$ ) led to an increased amount of fines following processing (rolling). Therefore, steep liquor was included in the diet as a protein source to decrease fines and help to prevent sorting or diet separation.

This experiment was conducted as a blind study for feedlot personnel involved, similar to Exp. 1 and Exp. 2. Each hybrid was assigned a letter designation prior to initiation of the experiment, and all records, feed sheets, commodity bays, and pen assignments were acknowledged by letter designation throughout the experiment. Several measures were taken to prevent crosscontamination between hybrids throughout the study. Each hybrid of corn was rolled separately and stored in its own commodity bay that was sealed on all sides except the entrance. Nontransgenic corn, grown at the University of Nebraska's Agricultural Research and Development Center, was utilized to clean out the mill and rolling system between hybrid processing. Based on DMI and transportation issues, grain was transported to the mill and processed at one time approximately once every $3 \mathrm{wk}$. At time of feeding, truck mixer boxes were cleaned out before and between each diet by feeding a diet that contained nontransgenic corn to nonstudy animals in the research unit. Steers were fed once daily in the morning using truck mixers (Rotomix, J-Star Industries, Inc., Dodge City, KS) with weighing capability. All scales for cattle and feeding were calibrated prior to study initiation.

Ingredient and bunk samples were taken weekly for all treatments. All ingredient and bunk samples were analyzed commercially (Dairy One, Ithaca, NY). Nutrient composition reported in Table 1 is based on ingredient analysis. As with Exp. 1 and Exp. 2, Monsanto (St. Louis, MO) evaluated presence or absence of the protein expressed by glyphosate tolerance genes using ELISA to confirm identity preservation.

Carcasses. Steers were marketed based on visual appraisal of fat thickness $(1.1 \mathrm{~cm})$ and were marketed to a commercial abattoir (IBP, West Point, NE) on d 144. Hot carcass weights and liver abscess scores were taken on the day of slaughter. Fat thickness at the 12th rib, USDA-called yield grade, USDA-called marbling score, and longissimus muscle area were recorded following a 24-h chill. Additionally, one neck tissue (brachiocephalicus muscle) sample was collected from each carcass for proximate analysis. Five randomly selected muscle samples from each pen ( 5 of 10 carcasses) were analyzed for moisture, protein, and fat similar to Exp. 1 and Exp. 2 at the Experiment Station Chemical Laboratory, University of Missouri-Columbia. Calculations for final weight, ADG, and feed efficiency were based on hot carcass weights adjusted to a $63 \%$ common yield. 
Table 2. Performance and carcass characteristics in Exp. 1 for steers fed either commercial reference hybrids, near-isogenic control hybrid, or Roundup Ready corn (event GA21) for $92 \mathrm{~d}$

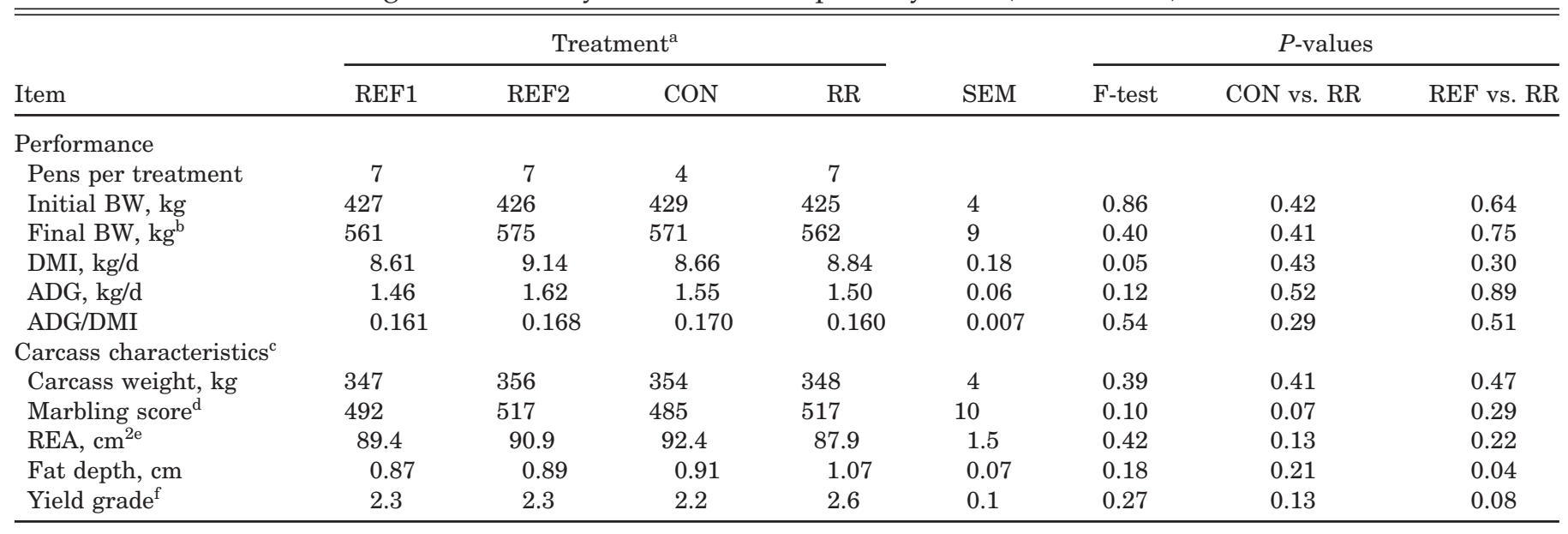

${ }^{a}$ REF1 = Reference (Asgrow RX826), REF2 = Reference (Asgrow 730), CON = Near isogenic control (DK626), RR = Roundup Ready (DK626RR; event GA21) corn.

${ }^{\mathrm{b}}$ Based on hot carcass weight adjusted by a common dress $(61.9 \%)$.

'Observations were carcass weight $(\mathrm{n}=174)$, Marbling score $(\mathrm{n}=171), \mathrm{REA}$, fat depth, and yield grade $(\mathrm{n}=157)$.

${ }^{\mathrm{d}}$ Marbling score in which Slight $50=450$, Small $50=550$.

${ }^{\text {e}} \mathrm{REA}$ is longissimus muscle area measured between the 12th and 13th ribs.

fYield grade was calculated using fat depth, longissimus muscle area, carcass weight, and kidney, pelvic, and heart fat (Meat Evaluation Handbook, 2001).

\section{Statistical Analysis}

Statistical analyses for feedlot growth performance and carcass characteristics were conducted using the MIXED procedure of SAS (SAS Inst., Inc., Cary, NC). Pen was the experimental unit for feedlot performance and carcass data in Exp. 1, Exp. 2, and Exp. 3. All experiments were analyzed as completely randomized designs. Two preplanned contrasts (RR vs. the average of REF1 and REF2; RR vs. CON) were utilized to compare the impact of glyphosate tolerance on performance and carcasses. An alpha level of 0.05 was assumed for significance to minimize type-I errors.

\section{Results}

\section{Experiment 1}

Steer ADG was not influenced $(P>0.05)$ by genetically enhanced corn hybrid in Exp. 1 (Table 2). Corn hybrid did cause significant variation in DMI based on the $F$-statistic $(P=0.05)$. However, no differences were detected in the preplanned contrasts between RR hybrid and CON or RR and the reference hybrids. Feed efficiency, measured as ADG/DMI, was not different ( $P$ $>0.05$ ) among hybrids, suggesting no negative impacts on performance due to insertion of glyphosate tolerance genes. Averaged among treatments, efficiencies were $0.165 \mathrm{~kg} \mathrm{ADG} / \mathrm{kg}$ DMI. Carcasses from cattle fed RR contained more fat $(P=0.04)$ than the average of the cattle fed reference hybrids. Similarly, yield grade differences between $\mathrm{RR}$ and the reference hybrids approached significance $(P=0.08)$. Marbling scores for steers fed RR were higher than for steers fed CON corn and approached significance $(P=0.07)$. Despite greater fat depth, marbling scores were not different $(P=0.29)$ between $R R$ and the average of the reference hybrids. However, the authors caution the reader that based on the $F$-statistic, little variation for fat depth and yield grade $(P>0.18)$ were attributable to corn hybrid. Marbling scores approached significance $(P=0.10)$ for the F-statistic. For almost all performance and carcass parameters measured, feeding $\mathrm{RR}$ resulted in performance intermediate to $\mathrm{CON}$ and the average of REF1 and REF2.

\section{Experiment 2}

Steers fed RR had similar ADG as steers fed either CON $(P>0.05)$ or conventional reference hybrids $(P>$ 0.05) in Exp. 2 (Table 3). Similar to Exp. 1, significant variation was observed across the hybrids for DMI based on the $F$-statistic $(P=0.05)$. Based on the preplanned contrasts, the RR hybrid was not significantly different than either the CON or the average of the two reference hybrids. Averaged among treatments, steers gained $1.56 \mathrm{~kg} / \mathrm{d}$ with feed efficiencies of $0.153 \mathrm{~kg}$ ADG/ kg DMI. Carcass characteristics, including hot carcass weight, marbling, fat depth, and REA were unaffected by dietary treatment $(P>0.05)$ based on the $F$-statistic. Based on preplanned contrasts, carcasses from RR fed steers contained more fat $(P=0.09)$ than carcasses from steers fed the reference hybrids; however, the F-statistic was not significant suggesting little variation due to corn hybrid.

\section{Experiment 3}

No differences were observed among treatments for performance and carcass measurements recorded (Ta- 
Table 3. Performance and carcass characteristics in Exp. 2 for steers fed either commercial reference hybrids, near-isogenic control hybrid, or Roundup Ready corn (event nk603) for $94 \mathrm{~d}$

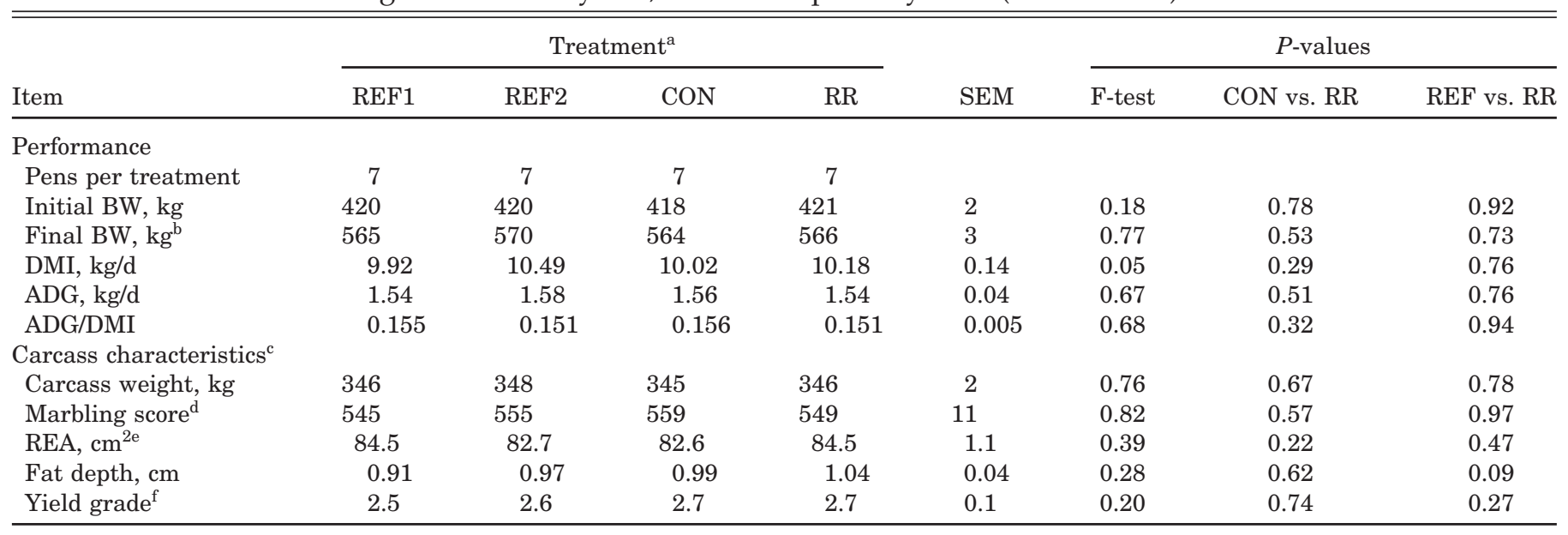

${ }^{a}$ REF1 = Reference hybrid DK647, REF2 = Reference hybrid RX740, CON = Near isogenic control hybrid RX670, and RR = Roundup Ready hybrid (event nk603).

${ }^{\mathrm{b}}$ Based on hot carcass weight adjusted by common dress $(61.1 \%)$.

'Observations were carcass weight $(n=174)$, Marbling score $(n=171)$, REA, fat depth, and yield grade $(n=157)$.

${ }^{\mathrm{d}}$ Marbling score in which Slight $50=450$, Small $50=550$.

${ }^{\text {e}} \mathrm{REA}$ is longissimus muscle area measured between the 12th and 13th ribs.

fYield grade was calculated using fat depth, longissimus muscle area, carcass weight, and kidney, pelvic, and heart fat (Meat Evaluation Handbook, 2001).

ble 4). No differences occurred between RR and CON for final BW, DMI, ADG, hot carcass weight, marbling, or fat depth. The main effect of corn treatment was not significant for any variable. However, preplanned contrasts suggested that cattle fed CON had numerically greater efficiency (ADG/DMI) compared with animals on the RR treatment and approached significance $(P=0.08)$, although feed efficiency was not different between RR treatment and reference hybrids. The authors caution the reader as the F-statistic for feed efficiency was not significant $(P=0.22)$ suggesting little variation due to corn being fed.
No differences in BW, DMI, ADG, or feed efficiency were observed between the average of REF1 and REF2 compared with steers fed RR. Feeding conventional reference hybrids resulted in slightly more $(P=0.05) 12$ thrib fat depth compared with the RR treatment. However, all steers were quite fat (1.6-cm fat depth). Fat depth was considerably greater in Exp. 3 than in Exp. 1 or Exp. 2. No other differences in carcass traits (hot carcass weight, marbling, or REA) were observed between RR and REF1 and REF2.

Meat composition is presented in Table 5. No differences were detected for moisture content of longissimus

Table 4. Performance and carcass characteristics in Exp. 3 for steers fed either commercial reference hybrids, near-isogenic control hybrid, or Roundup Ready corn (event nk603) for $144 \mathrm{~d}$

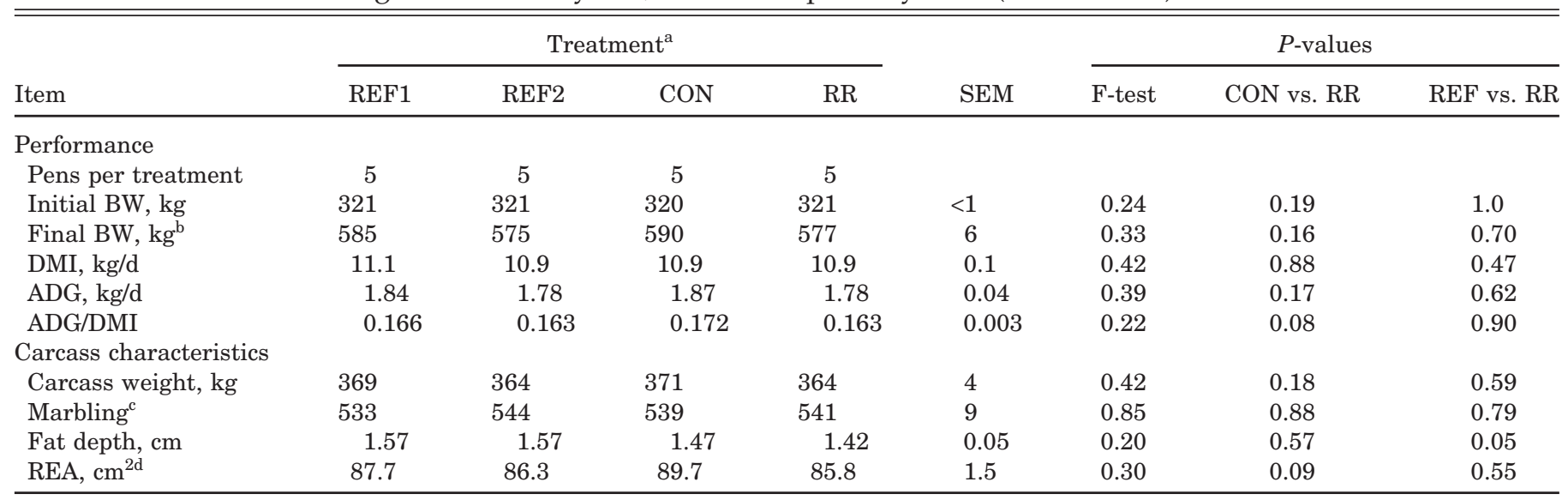

${ }^{\text {a} R E F 1 ~=~ R e f e r e n c e ~ h y b r i d ~ D K 647, ~ R E F 2 ~=~ R e f e r e n c e ~ h y b r i d ~ R X 740, ~ C O N ~=~ N e a r ~ i s o g e n i c ~ c o n t r o l ~ h y b r i d ~ R X 670, ~ a n d ~ R R ~=~ R o u n d u p ~ R e a d y ~}$ hybrid (event nk603).

${ }^{\mathrm{b}}$ Based on hot carcass weight adjusted to a common dress $(63 \%)$.

${ }^{\mathrm{c}}$ Marbling score in which Small $0=500$, Small $50=550$.

${ }^{\mathrm{d}} \mathrm{REA}$ is longissimus muscle area measured between the 12th and 13th ribs. 
Table 5. Muscle composition of selected muscles from Exp. 1, Exp. 2, and Exp. $3^{\text {a }}$

\begin{tabular}{|c|c|c|c|c|c|c|}
\hline & REF1 & REF2 & $\mathrm{CON}$ & $\mathrm{RR}$ & $\mathrm{SE}$ & $P$-value of F-test \\
\hline \multicolumn{7}{|c|}{ Exp. 1-longissimus thoracis ${ }^{b}$} \\
\hline Moisture & 72.3 & 72.1 & 73.5 & 72.3 & 0.5 & 0.30 \\
\hline Protein & 22.3 & 22.0 & 22.1 & 22.0 & 0.3 & 0.81 \\
\hline Fat & 3.9 & 4.0 & 3.5 & 4.1 & 0.4 & 0.73 \\
\hline \multicolumn{7}{|c|}{ Exp. 2-longissimus thoracis ${ }^{\mathrm{c}}$} \\
\hline Moisture & 71.8 & 71.7 & 71.4 & 71.7 & 0.3 & 0.69 \\
\hline Protein & 23.8 & 23.9 & 24.0 & 23.7 & 0.3 & 0.92 \\
\hline Fat & 4.0 & 4.1 & 4.6 & 4.3 & 0.2 & 0.41 \\
\hline \multicolumn{7}{|c|}{ Exp. 3-Brachiocephalicus muscle ${ }^{c}$} \\
\hline Moisture & 75.6 & 75.1 & 75.2 & 76.2 & 0.5 & 0.47 \\
\hline Protein & 20.5 & 20.0 & 20.2 & 19.6 & 0.3 & 0.23 \\
\hline Fat & 3.4 & 3.9 & 3.8 & 3.5 & 0.5 & 0.84 \\
\hline
\end{tabular}

${ }^{a}$ Percent as-is, expressed as $\mathrm{g} / 100 \mathrm{~g}$.

${ }^{\mathrm{b}} \mathrm{REF} 1$ = Reference (Asgrow RX826), REF2 = Reference (Asgrow 730), CON = Near isogenic control (DK626), $\mathrm{RR}=$ Roundup Ready (DK626RR; event GA21) corn.

${ }^{\mathrm{c}} \mathrm{REF} 1$ = Reference hybrid DK647, REF2 = Reference hybrid RX740, CON = Near isogenic control hybrid $\mathrm{RX670,}$ and RR = Roundup Ready hybrid (event nk603).

thoracis in either Exp. 1 or Exp. 2. Moisture content in Exp. 1 was $72.6 \%$ and $71.7 \%$ in Exp. 2. In Exp. 3, muscle composition was measured on a neck muscle (brachiocephalicus). Moisture content was not affected $(P>0.20)$ by corn hybrid fed and averaged 75.5\% in Exp. 3. Protein, expressed on an as-is basis, was not affected by hybrid in Exp. 1, Exp. 2, or Exp. 3 and averaged 22.1, 23.9 , or $20.1 \%$, respectively. Similarly, fat content was not different among dietary treatments. Fat averaged 3.9, 4.3, and 3.7\% for Exp. 1, Exp. 2, and Exp. 3, respectively. Interestingly, despite considerably greater fat depth in Exp. 3 compared with Exp. 1 or Exp. 2, fat content on an as-is basis was not higher for steers in Exp. 3. When corrected for moisture content, percentage fat in these muscle samples were $15.1 \%$ in Exp. 3 and 14.2 and 15.2\% in Exp. 1 and Exp. 2, respectively.

\section{Discussion}

Lack of differences among treatments observed in all three experiments agrees with previous research evaluating glyphosate-tolerant corn and soybeans fed to dairy cattle (Donkin et al., 2003; Hammond et al., 1996), pigs (Cromwell et al., 2001; Stanisiewski et al., 2001; Gaines et al., 2001a), and poultry (Gaines et al., 2001b; Taylor et al., 2003). Donkin et al. (2003) utilized silage and grain from Roundup Ready corn (event GA21) to examine effects of transgenic crops on feed intake, milk yield, and milk composition for sixteen lactating Holstein cows. The Roundup Ready treatment was contrasted against its control hybrid (DK626). Diets consisted of $62 \%$ corn silage and $17 \%$ corn grain from either the RR corn or the control corn. No differences in DMI, 21.5 vs. $21.9 \pm 0.4$; milk production, 29.4 vs. $29.5 \pm 0.4$; or milk composition were observed between RR and its control, respectively. The authors suggested those data demonstrated that lactating cows fed either the RR or the nontransgenic corn and silage perform similarly. Grant et al. (2003) also fed Roundup
Ready corn silage and grain to lactating cows. In their study, differences observed were related to nutritional quality as a result of environmental conditions at silage harvest rather than transgenic traits. In contrast, Ipharraguerre et al. (2003) conducted a similar dairy cow study and did not detect any lactation performance differences using silages of comparable quality. Likewise, diets with RR corn had comparable feeding value to control and other commercially available hybrids fed to swine (Bressner et al., 2002; Fischer et al., 2002).

The differences observed in ADG and feed efficiency appear to be within normal ranges observed in the feedlot industry. While no data exist on these reference hybrids, some comparisons can be made to other research station reports with dry-rolled corn finishing diets. Owens et al. (1997) summarized grain source and processing data, including 183 trials with dry-rolled corn fed to finishing cattle. Gain, DMI, and feed conver$\operatorname{sion}(\mathrm{DMI} / \mathrm{ADG}$ ) averaged $1.45 \mathrm{~kg} / \mathrm{d}, 9.45 \mathrm{~kg} / \mathrm{d}$, and 6.57 , respectively. Considerable variation exists in feedlot performance; however, no standard errors were presented for these averages. In our experiments, feed:gain averaged 6.07, 6.53, and 6.02 for Exp. 1, Exp. 2, and Exp. 3, respectively. Therefore, we conclude that feeding Roundup Ready corn has no impact on livestock production compared with nontransgenic hybrids and results in average performance.

A power test was conducted on each experiment for ADG, DMI, and feed efficiency using PROC MIXED procedures of SAS (SAS Inst. Inc., Cary, NC). The observed mean square error from each performance parameter was used. The power test treatment structure was used where maximum power is evaluated. For these experiments with four treatments, this approach assumed two treatments were greater than the other two comparable treatments. Treatment differences were evaluated based on the observed range (which varied from 1.8 to $10.5 \%$ change), a $5 \%$ change in treatment means, and a $10 \%$ change in treatment means. 
Table 6. Power analysis results for Exp. 1, Exp. 2, and Exp. 3 performance measurements to determine likelihood of a type-II error. Three treatment differences were evaluated for power using actual observed differences in means, a $5 \%$ change in means, and a $10 \%$ change in means

\begin{tabular}{|c|c|c|c|c|c|}
\hline \multirow[b]{2}{*}{ Variable } & \multirow[b]{2}{*}{ Difference } & \multirow[b]{2}{*}{$\%$ change $^{a}$} & \multicolumn{3}{|c|}{ Power $P$-value } \\
\hline & & & Observed change & $5 \%$ change & $10 \%$ change \\
\hline \multicolumn{6}{|c|}{ Experiment 1} \\
\hline DMI & 0.53 & 6.0 & 0.882 & 0.732 & 1.00 \\
\hline $\mathrm{ADG}$ & 0.16 & 10.5 & 0.752 & 0.203 & 0.681 \\
\hline ADG/DMI & 0.010 & 6.1 & 0.257 & 0.214 & 0.717 \\
\hline \multicolumn{6}{|c|}{ Experiment 2} \\
\hline DMI & 0.57 & 5.6 & 0.833 & 0.811 & 1.00 \\
\hline $\mathrm{ADG}$ & 0.04 & 2.6 & 0.186 & 0.331 & 0.907 \\
\hline ADG/DMI & 0.005 & 3.3 & 0.171 & 0.205 & 0.683 \\
\hline \multicolumn{6}{|c|}{ Experiment 3} \\
\hline DMI & 0.2 & 1.8 & 0.318 & 0.914 & 1.00 \\
\hline $\mathrm{ADG}$ & 0.09 & 5.0 & 0.322 & 0.322 & 0.898 \\
\hline ADG/DMI & 0.009 & 5.4 & 0.567 & 0.545 & 0.993 \\
\hline
\end{tabular}

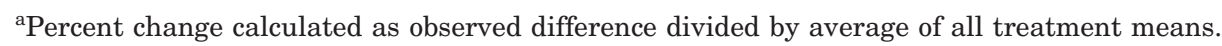

For Exp. 1, the observed difference resulted in sufficient power (0.88) to avoid type-II errors for DMI as well as ADG (0.75; Table 6). In contrast, feed efficiency changes of $10 \%$ were necessary to detect differences with a power approaching 0.80 for Exp. 1. In both Exp. 2 and Exp. 3 , a $10 \%$ change in treatment means was adequate for a power test of 0.80 except for feed efficiency in Exp. 2 , which approached 0.70 power. The power test conducted here is dependent on variation, the difference between treatments, and number of replications. The power test supports that between a 5 to10\% change in performance variables was adequately detected with the implemented experimental designs. The observed differences are not as meaningful as the percent change evaluated but are included for reference.

Carcass characteristics were evaluated similar to performance data. Because little variation existed for carcass weight, the power was greater than 0.90 for a $5 \%$ change in all three experiments. A $10 \%$ change in marbling and longissimus area resulted in power greater than 0.90 . Fat depth was more variable and the observed differences had a power of 0.50 to 0.70 for all three experiments. The observed difference for fat depth was greater than a $10 \%$ change for the observed fat depth in these experiments. These power test data suggest that our conclusions are appropriate, and no differences exist between Roundup Ready corn and nontransgenic corn.

\section{Implications}

Inclusion of the glyphosate-tolerant gene(s) and the subsequent proteins that are produced in corn did not lead to practically important differences in animal growth performance or carcass composition. Feeding Roundup Ready corn to feedlot cattle had no effect on growth performance and seems equivalent to conventional, nontransgenic hybrids. Diets containing geneti- cally enhanced corn should be balanced just as with conventional corn (i.e., based on nutrient analyses and ingredient quality).

\section{Literature Cited}

AOAC. 1999. Official Methods of Analysis (16th Ed.). Assoc. Offic. Anal. Chem.. AOAC International, Gaithersburg, MD.

Bressner, G. E., Y. Hyun, E. P. Stanisiewski, G. F. Hartnell, and M. Ellis. 2002. A comparison of swine performance when fed diets containing Roundup Ready(R) (event NK603) or conventional corn lines. J. Anim. Sci. 80(Suppl. 2):63. (Abstr.)

Clark, J. H., and I. R. Ipharraguerre. 2001. Livestock performance: Feeding biotech crops. J. Dairy Sci. 84(E. Suppl.):9-18.

Consortium. 1988. Guide for the Care and Use of Agriculture Animals in Agriculture Research and Teaching. Assoc. Headquarters, Savoy, IL.

Cromwell, G. L., M. D. Lindemann, J. H. Randolph, E. P. Stanisiewski, and G. F. Hartnell. 2001. Soybean meal from Roundup Ready $(R)$ or conventional soybeans in diets for growing-finishing pigs. J. Anim. Sci. 79(Suppl. 1):318 (Abstr.)

Donkin, S. S., J. C. Velez, A. K. Totten, E. P. Stanisiewski, and G. F. Hartnell. 2003. Effects of feeding silage and grain from glyphosate tolerant or insect-protected corn hybrids on feed intake, ruminal digestion, and milk production in dairy cattle. J. Dairy Sci. (In Press).

Fischer, R. L., A. J. Lewis, P. S. Miller, E. P. Stanisiewski, and G. F. Hartnell. 2002. Comparison of swine performance when fed diets containing Roundup Ready(R) corn, parental line corn, or conventional corn grown during 2000 in Nebraska. J. Anim. Sci. 80(Suppl. 1): 224. (Abstr.)

Gaines, A. M., G. L. Allee, and B. W. Ratliff. 2001a. Swine digestible energy evaluations of Bt (MON810) and Roundup Ready(R) corn compared with commercial varieties. J. Anim. Sci. 79(Suppl. 1):109. (Abstr.)

Gaines, A. M., G. L. Allee, and B. W. Ratliff. 2001b. Nutritional evaluation of Bt (MON810) and Roundup Ready(R) corn compared with commercial hybrids in broilers. J. Anim. Sci. 79(Suppl. 1):51. (Abstr.)

Grant, R. J., K. C. Fanning, D. Kleinshmit, E. P. Stanisiewski, and G. F. Hartnell. 2003. Influence of glyphosate tolerant (event nk603) and corn root worm protected (event MON863) corn silage and grain on feed consumption and milk production in Holstein cattle. J. Dairy Sci. 86:1707-1715. 
Hammond, B. G., J. L. Vicini, G. F. Hartnell, M. W. Naylor, C. D. Knight, E. H. Robinson, R. L. Fuchs, and S. R. Padgette. 1996. The feeding value of soybeans fed to rats, chickens, catfish, and dairy cattle is not altered by genetic incorporation of glyphosate tolerance. J. Nutr. 126:717-727.

Ipharraguerre, I. R., R. S. Younker, J. H. Clark, E. P. Stanisiewski, and G. F. Hartnell. 2003. Performance of lactating dairy cows fed corn as whole plant silage and grain produced from a glyphosatetolerant hybrid (event nk603). J. Dairy Sci. (accepted).

AMSA. 2001. Meat Evaluation Handbook. Am. Meat Sci. Assoc. Savoy, IL.

NRC. 1996. Nutrient Requirements of Beef Cattle. 7th ed. National Academy Press, Washington, DC.

Owens, F. N., D. S. Secrist, W. J. Hill, and D. R. Gill. 1997. The effect of grain source and grain processing on performance of feedlot cattle: A review. J. Anim. Sci. 75:868-879.

Sidhu, R. S., B. G. Hammond, R. L. Ruchs, J. Mutz, L. R. Holden, B. George, and T. Olson. 2000. Glyphosate-tolerant corn: The composition and feeding value of grain from glyphosate-tolerant corn is equivalent to that of conventional corn (Zea mays L.). J. Agric. Food Chem. 48:2305-2312.

Stanisiewski, E. P., G. F. Hartnell, and D. R. Cook. 2001. Comparison of swine performance when fed diets containing Roundup Ready(R) corn (GA21), parental line, or conventional corn. J. Anim. Sci. 79(Suppl. 1):319. (Abstr.)

Steinrücken, H. C., and N. Amrhein. 1980. The herbicide glyphosate is a potent inhibitor of 5-enolpyruvylshikimate-3-phosphate synthase. Biochem. Biophys. Res. Commun. 94:1207-1212.

Taylor, M. L., G. F. Hartnell, S. G. Riordan, M. A. Nemeth, K. Karunanandaa, B. George, and J. D. Astwood. 2003. Comparison of broiler performance when fed diets containing grain from Roundup Ready(R) (nk603), YieldGard(R) $\times$ Roundup Ready(r) (MON810 $\times$ nk603), non-transgenic control, or commercial corn. J. Poultry Sci. 82:443-453.

USDA. 2002. National Agricultural Statistics Service Acreage Publication. Accessed: http://usda.mannlib.cornell.edu/reports/nassr/ field/pcp-bba/acrg0602.pdf. Accessed April 10, 2001. 